\title{
Earthworm assemblages in an ecotone between forest and arable field and their relations with soil properties
}

\author{
Josef Zeithaml(1), Václav Pižl(2) and Petr Sklenička(1) \\ ${ }^{(1)}$ Czech University of Life Sciences, Faculty of Environmental Sciences, Prague, Kamýcká 129, CZ-165 21 Prague, Czech Republic. \\ E-mail: josef.zeithaml@cuzk.cz, sklenicka@fzp.czu.cz ${ }^{(2)}$ Institute of Soil Biology, Biology Centre AS CR, Na Sádkách 7, CZ-37005 České \\ Budějovice, Czech Republic. E-mail: pizl@upb.cas.cz
}

\begin{abstract}
The objective of this work was to assess the effects of a forest-field ecotone on earthworm assemblages. Five sites (blocks) differing in the type of crop rotation used in the field were studied in Central Bohemia, Czech Republic. In each block, sampling was carried out in seven parallel rows perpendicular to a transect from a forest (oak or oak-pine) to the centre of a field, both in spring and autumn 2001-2003. Individual rows were located in the forest ( $5 \mathrm{~m}$ from the edge), in the forest edge, and in the field (at 5,10 , 25,50 and $100 \mathrm{~m}$ distances from the forest edge). The density and biomass of earthworms were lowest in the forest, increased markedly in the forest edge, decreased again at 5 or $10 \mathrm{~m}$ distance from the forest edge and then continuously increased along the distance to the field boundary. The highest number of species was found in the forest edge and in the field boundary. Individual species differed in their distribution along the transect. Both density and biomass of earthworms were correlated with distance from forest edge, soil organic matter content, soil porosity, and water infiltration rate.
\end{abstract}

Index terms: edge effect, landscape mosaic, Lumbricidae.

\section{Comunidades de minhocas em um ecótono entre floresta e campo arável e suas relações com as propriedades do solo}

\begin{abstract}
Resumo - O objetivo deste trabalho foi avaliar os efeitos de um ecótono entre floresta e campo arável sobre comunidades de minhocas. Cinco locais (blocos) com diferentes tipos de rotação de culturas utilizados no campo foram estudados na Boêmia Central, República Tcheca. Em cada bloco, amostragens foram feitas em sete linhas paralelas perpendiculares a um transecto de floresta (carvalho ou carvalho e pinheiro), em direção ao centro de um campo, na primavera e no outono de 2001-2003. Linhas individuais foram marcadas na floresta (a $5 \mathrm{~m}$ da borda), na borda da floresta e no campo (a 5, 10, 25, 50 e $100 \mathrm{~m}$ da borda da floresta). A densidade e biomassa das minhocas foi menor na floresta, aumentou marcadamente na borda da floresta, decaiu novamente a 5 ou $10 \mathrm{~m}$ de distância da borda da floresta e aumentou continuamente com a distância até o limite do campo. O maior número de espécies foi encontrado na borda da floresta e no limite do campo. As espécies apresentaram distribuições diferentes ao longo do transecto. Tanto a densidade quanto a biomassa de minhocas foram correlacionadas com a distância da borda da floresta, o conteúdo de matéria orgânica do solo, a porosidade do solo e a infiltração de água.
\end{abstract}

Termos para indexação: efeito de borda, mosaico de paisagem, Lumbricidae.

\section{Introduction}

In Central Europe, most lowland forests are fragmented due to the long-lasting human activity. Patches of forests are mostly surrounded by agricultural land. Ecotones between forests and arable fields or grasslands form a remarkable part of the landscape mosaic. Therefore, the research on ecotones is important for a better understanding of the effects of landscape pattern on ecosystem functions, and could also add to a sound scientific justification of regulatory protection of biological diversity and of landscape management planning.
Most studies on biodiversity of ecotones have dealt with plants, birds, small mammals and several groups of insects. Soil fauna has been scarcely studied in this context. Some data are available on the diversity of nematodes (Háněl, 2000; Imaz et al., 2002), enchytraeids (Nowak, 2004) and collembolans (Slawski \& Slawska, 2000) across ecotones of different scales (micro or mesoecotones). There are only a few studies comparing earthworm assemblages in arable land and adjacent forests (Whalen, 2004; Smith et al., 2008) or dealing with earthworm dispersal in the agricultural 
landscape (Mather \& Christensen, 1995). Three studies on earthworms in ecotone systems have been published so far. Arujo \& Lopez-Fernandez (1999) examined earthworm populations in forest-savanna ecotones in Venezuela. In Sweden, Lagerlöf et al. (2002) compared earthworm assemblages of a non-cultivated field boundary and of the adjacent arable field at different distances from the boundary. Makulec (2004) studied earthworms in a midfield shelterbelt, an adjacent arable field and an ecotone between both ecosystems in western Poland. However, some additional data are available for comparison from studies dealing with changes of earthworm assemblages during the secondary succession in abandoned arable fields (Scheu, 1992; Pižl, 1999; Slávecz \& Csuzdi, 2007).

The aim of this study was to examine the effect of forest edges on species richness and quantitative parameters of earthworm assemblages in the agricultural landscape of Central Europe. As our study was conducted within a multidisciplinary project investigating the effects of field margins on water dynamics in arable soils, particular attention was paid to the agriculturally used part of the studied ecotones.

\section{Materials and Methods}

The research was carried out in Central Bohemia (Czech Republic) near the town Kostelec nad Černými lesy, ca. $35 \mathrm{~km}$ east of Prague. Five sites (blocks) representing forest-field ecotones with different types of crop rotation were studied. The distances between sites ranged from 0.5 to $3 \mathrm{~km}$. The forest parts of the sites received no forestry intervention during the study, and the field parts were ploughed each year in autumn. Additional data about the sites are given in Table 1. At each site, soil sampling was carried out in seven parallel rows perpendicular to a transect from an oak or oak-pine forest towards the centre of the field (ecotone lines). Individual rows were located in the forest interior ( $\mathrm{A}$, at $5 \mathrm{~m}$ from the edge), in the forest edge (E), and in the field at distances of $5(\mathrm{P} 1), 10$ (P2), 25 (P3), 50 (P4) and $100 \mathrm{~m}$ (P5) from the edge of the forest. Six samples (each with $625 \mathrm{~cm}^{2}$ in area and $30 \mathrm{~cm}$ in depth) were taken from each row in spring and autumn 2001-2003. The distances between sampling points were dependent upon the sizes of individual sites and were of $25 \mathrm{~m}$ in block 3,30 m in blocks 1 and 2, $35 \mathrm{~m}$ in block 5 , and $50 \mathrm{~m}$ in block 4 . Earthworms were collected by hand sorting from the soil samples. In order to expel worms from deeper soil layers, $0.5 \mathrm{~L}$ of $0.25 \%$ formaldehyde was applied three times within a period of 20 minutes into each hole. A total of 5,402 earthworms were obtained from 1,260 samples.

The lumbricids obtained were preserved in $7 \%$ formaldehyde and identified (including the ones in juvenilestages) to the species level. Preserved specimens were weighed to determine earthworm biomass, and no corrections were made for gut content or fresh weight. The earthworm assemblages of individual rows were characterized by density, biomass, composition of species and their relative densities.

Table 1. Geographical position of individual blocks, tree composition in forests, crops planted in the fields in the studied years, and basic soil parameters (means $\pm S D, n=6$ ), measured in spring 2002 .

\begin{tabular}{|c|c|c|c|c|c|}
\hline \multirow[t]{2}{*}{ Description variables $^{(1)}$} & \multicolumn{5}{|c|}{ Block } \\
\hline & 1 & 2 & 3 & 4 & 5 \\
\hline \multirow{3}{*}{ GPS coordinates } & \multicolumn{5}{|c|}{ Site characteristics } \\
\hline & $49^{\circ} 58^{\prime} 45.77^{\prime \prime} \mathrm{N}$ & $49^{\circ} 58^{\prime} 46.04^{\prime \prime} \mathrm{N}$ & $49^{\circ} 58^{\prime} 46.56^{\prime \prime} \mathrm{N}$ & $50^{\circ} 0^{\prime} 45.75^{\prime \prime} \mathrm{N}$ & $50^{\circ} 0^{\prime} 55.47^{\prime \prime} \mathrm{N}$ \\
\hline & $14^{\circ} 52^{\prime} 16.87^{\prime \prime} \mathrm{E}$ & $14^{\circ} 52^{\prime} 25.29^{\prime \prime} \mathrm{E}$ & $14^{\circ} 52^{\prime} 33.72^{\prime \prime} \mathrm{E}$ & $14^{\circ} 51^{\prime} 12.82^{\prime \prime} \mathrm{E}$ & $14^{\circ} 51^{\prime} 15.01 " \mathrm{E}$ \\
\hline \multirow[t]{2}{*}{ Tree species } & Oak & Oak-Pine & Oak-Pine & Oak-Pine & Oak \\
\hline & \multicolumn{5}{|c|}{ Crop season } \\
\hline 2001 & Winter wheat & Winter wheat & Grass-clover & Winter wheat & Grain-legumes \\
\hline 2002 & Rape & Winter wheat & Winter wheat & Winter wheat & Grain-legumes \\
\hline \multirow[t]{2}{*}{2003} & Barley & Barley & Barley & Barley & Grain-legumes \\
\hline & \multicolumn{5}{|c|}{ Soil parameters } \\
\hline $\mathrm{PH}$ & $6.10 \pm 0.40$ & $6.35 \pm 0.66$ & $6.81 \pm 0.31$ & $6.62 \pm 0.34$ & $6.55 \pm 0.80$ \\
\hline $\mathrm{C}_{\mathrm{ox}}(\%)$ & $0.94 \pm 0.06$ & $1.21 \pm 0.33$ & $1.13 \pm 0.16$ & $0.96 \pm 0.24$ & $0.77 \pm 0.12$ \\
\hline $\mathrm{Na}\left(\mathrm{mg} \mathrm{kg}^{-1}\right)$ & $52.0 \pm 14.1$ & $41.2 \pm 8.2$ & $46.3 \pm 13.8$ & $47.3 \pm 26.2$ & $52.8 \pm 15.49$ \\
\hline $\mathrm{K}\left(\mathrm{mg} \mathrm{kg}^{-1}\right)$ & $104.2 \pm 14.5$ & $75.3 \pm 17.1$ & $93.8 \pm 45.4$ & $114.7 \pm 72.6$ & $103.8 \pm 25.8$ \\
\hline $\mathrm{Ca}\left(\mathrm{mg} \mathrm{kg}^{-1}\right)$ & $757.7 \pm 65.2$ & $806.8 \pm 109.1$ & $888.0 \pm 142.9$ & $843.5 \pm 106.1$ & $862.7 \pm 358.6$ \\
\hline $\mathrm{P}_{\text {tot }}\left(\mathrm{mg} \mathrm{kg}^{-1}\right)$ & $647.2 \pm 70.7$ & $643.0 \pm 85.8$ & $607.8 \pm 47.2$ & $718.2 \pm 37.3$ & $536.5 \pm 40.7$ \\
\hline $\mathrm{P}_{\text {avail }}\left(\mathrm{mg} \mathrm{kg}^{-1}\right)$ & $57.8 \pm 9.1$ & $57.8 \pm 23.2$ & $48.2 \pm 7.1$ & $107.5 \pm 18.3$ & $55.8 \pm 16.7$ \\
\hline $\mathrm{P}_{\mathrm{v}}\left(\mathrm{mg} \mathrm{kg}^{-1}\right)$ & $22.2 \pm 1.7$ & $23.3 \pm 10.1$ & $18.8 \pm 3.3$ & $47.2 \pm 23.9$ & $20.7 \pm 5.9$ \\
\hline
\end{tabular}

${ }^{(1)} \mathrm{C}_{\mathrm{ox}}$, organic carbon; $\mathrm{P}_{\text {tot }}, \mathrm{P}_{\mathrm{avai}}, \mathrm{P}_{\mathrm{v}}$, total, available and water-soluble phosphorus, respectively. 
In addition, chemical parameters of soil were measured from soil samples taken from each ecotone row in spring 2002. Soil $\mathrm{pH}$ and the contents of organic carbon $\left(\mathrm{C}_{\mathrm{ox}}\right), \mathrm{K}, \mathrm{Na}, \mathrm{Ca}$ and total, available and water soluble $\mathrm{P}$ were measured using standardized methods (Zbíral et al., 1997). Infiltration rate and soil porosity at depths of 10, 20 and $30 \mathrm{~cm}$ were measured in each row in spring and autumn 2001-2003, according to Sklenička et al. (2002) methods.

Differences between earthworm densities and biomasses along the transect were tested by the distribution-free Kruskal-Wallis ANOVA and subsequently by the Mann-Whitney-U-Test for the corresponding pairs of rows. Spearman's coefficient was used to assess correlations between earthworm density and biomass and selected physical parameters of soil (SPSS 15.0 for Windows). An ordination based on principal component analysis (PCA), calculated using the CANOCO program, was used for visualizing relations among environmental and earthworm assemblage parameters.

\section{Results and Discussion}

Eleven earthworm species and subspecies were identified, namely Aporrectodea caliginosa Savigny, 1826; Aporrectodea trapezoides Dugés, 1828; Aporrectodea rosea Savigny, 1826; Dendrobaena octaedra Savigny, 1826; Dendrodrilus rubidus Savigny, 1826; Eiseniella tetraedra Savigny, 1826; Lumbricus castaneus Savigny, 1826; Lumbricus rubellus Hoffmeister, 1843; Lumbricus terrestris Linnaeus, 1758; Octolasion lacteum Örley, 1881; and Proctodrilus antipai Michaelsen, 1891. The species numbers ranged from 7 to 10 per block. Species typical of agroecosystems (A. caliginosa, A. rosea, D. octaedra, L. rubellus, L. terrestris, and $O$. lacteum) were found in all blocks. On the other hand, $P$. antipai, an earthworm scarcely reported in cultivated areas, was only found in one block and the remaining species in two or three blocks. Aporrectodea caliginosa predominated in all blocks (Table 2). The highest number of species was found in the forest edge and in the field boundary (Figure 1).

Three species, A. caliginosa, A. rosea and L. terrestris, were recorded in all rows of the transect. Among them, A. caliginosa showed a significant trend of increasing density from the boundary of the field towards the centre, while $A$. rosea and $L$. terrestris preferred the forest edge. Other species were found irregularly in some rows. The endogeic Proctodrilus antipai preferred arable soil, whereas the epigeic Dendrobaena octaedra and Lumbricus rubellus and the endogeic Octolasion lacteum showed strong affinity to the forest edge (Figure 1).

The position within the transect significantly affected the density and biomass of earthworms. In general, both parameters were lowest in the forest interior, increased markedly in the forest edge, decreased again at a 5 or 10-m distance from the forest edge and then increased successively along the distance from the forest edge (Figure 2). The same pattern was observed in all blocks and years of the study. Earthworm density and biomass were positively correlated with the distance from the forest edge towards the centre of the field and with soil

Table 2. List of earthworm species and sub-species and their relative density (\%) recorded from individual blocks.

\begin{tabular}{lccccc}
\hline Earthworm species & \multicolumn{5}{c}{ Block } \\
\cline { 2 - 6 } & 1 & 2 & 3 & 4 & 5 \\
\hline A. caliginosa & 75.9 & 88.3 & 92.7 & 82.6 & 77.4 \\
A. trapezoides & 0.2 & 0.8 & 0.2 & 0.8 & 3.5 \\
A. rosea & 17.4 & 9.0 & 3.6 & 9.0 & 15.3 \\
D. octaedra & 0.5 & 0.4 & 0.2 & 0.2 & 0.1 \\
D. rubidus & 0.2 & - & 0.1 & - & - \\
E. tetraedra & 0.2 & 0.2 & - & - & - \\
L. castaneus & 0.2 & 0.4 & 0.2 & - & - \\
L. rubellus & 0.3 & 0.1 & 0.3 & 0.3 & 0.3 \\
L. terrestris & 2.6 & 0.7 & 1.5 & 1.7 & 2.0 \\
O. lacteum & 2.4 & 0.1 & 0.8 & 5.4 & 1.4 \\
P. antipai & - & - & 0.4 & - & - \\
\hline
\end{tabular}

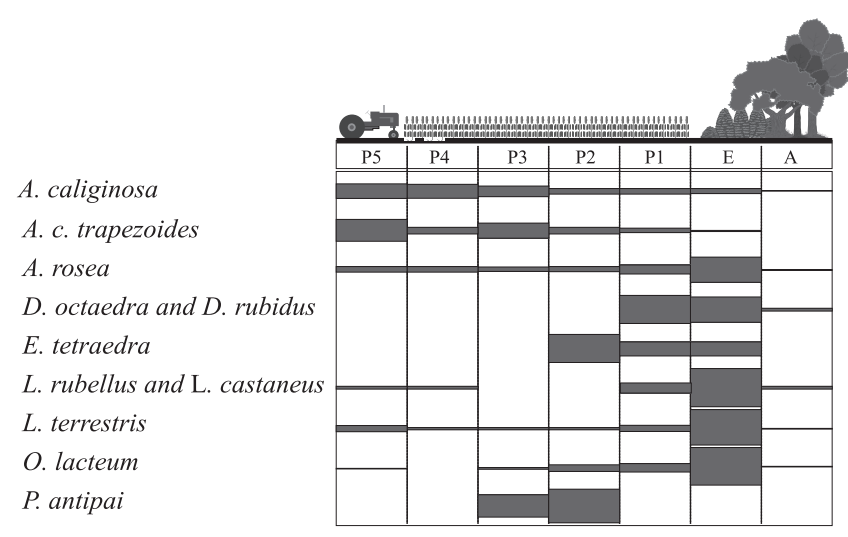

Figure 1. Distribution of earthworms along the transect from oak forest to arable field. Bar width indicates the relative proportion (\%) of the total number of individuals. A, E, P1, P2, P3, P4 and P5: ecotone rows located in the forest interior; in the forest edge; and in the field distances of 5, $10,25,50$ and $100 \mathrm{~m}$ from the forest edge, respectively 
organic matter content, moisture, porosity and water infiltration rate (Figure 3). Significant correlations between both quantitative parameters of earthworm assemblages and soil porosity up to the depth of $30 \mathrm{~cm}$ and water infiltration rate were found in all years of the study (Table 3 ).

In accordance with Leopold's theory (Leopold, 1933), which states that diversity and organism density will be higher in ecotones than in adjacent ecosystems, the highest numbers of earthworm species were recorded in the forest edge and in the field boundary. No species showed a preference for the field boundary, whereas five preferred the forest edge. Of those, D. octaedra and L. rubellus belonged to epigeic, $A$. rosea and $O$. lacteum to endogeic, and $L$. terrestris to anecic earthworms. The observed preference of epigeic species for the forest edge agrees
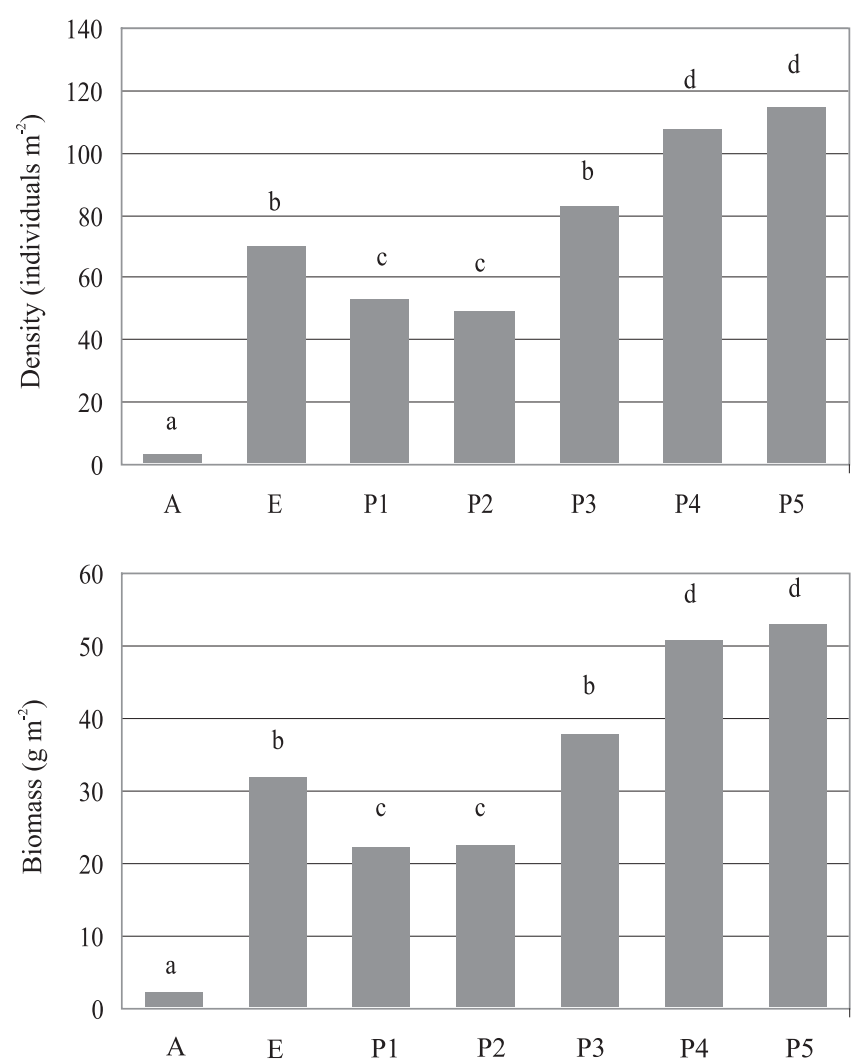

Figure 2. General averages of earthworm density and biomass along the transect from oak forest to arable field. A, E, P1, P2, P3, P4 and P5: ecotone rows located in the forest interior; in the forest edge; and in the field distances of 5, 10, 25, 50 and $100 \mathrm{~m}$ from the forest edge, respectively. Bars with equal letters above it indicate that means do not differ by Kruskal-Wallis H Test at $5 \%$ of probability $(n=180)$. with the findings by Scheu (1992), who reported a continuous increase of their biomass during secondary succession in abandoned fields until the establishment of woody vegetation. Both epigeic species found in this study live in the litter and humus layers or can sometimes penetrate a little deeper into loose mineral soil (particularly L. rubellus). They are susceptible to soil cultivation, since it destroys the superficial soil layer. In general, they are much more abundant in



Figure 3. Principal component analysis biplot of earthworm density (Abund) and biomass (Biom), distance from forest edge (Dist) and soil parameters (Por10, Por20, Por30: porosity of the soil at the depth of 10,20 and $30 \mathrm{~cm}$; Inf, infiltration rate; Moist, soil moisture; $\mathrm{C}_{\mathrm{ox}}$, organic carbon; $\mathrm{P}_{\text {tot }}, \mathrm{P}_{\mathrm{v}}, \mathrm{P}_{\text {avail }}$ : total, water-soluble and available phosphorus.

Table 3. Spearman's correlation coefficient $(n=60)$ between earthworm density and biomass and selected physical soil parameters.

\begin{tabular}{|c|c|c|c|c|}
\hline \multirow{2}{*}{$\begin{array}{l}\text { Earthworm } \\
\text { parameter }\end{array}$} & \multicolumn{3}{|c|}{ Soil porosity } & \multirow[t]{2}{*}{ Infiltration rate } \\
\hline & $0-10 \mathrm{~cm}$ & $10-20 \mathrm{~cm}$ & $20-30 \mathrm{~cm}$ & \\
\hline & \multicolumn{4}{|c|}{2001} \\
\hline Density & 0.211 & $0.395 * *$ & $0.411 * *$ & 0.024 \\
\hline \multirow[t]{2}{*}{ Biomass } & 0.181 & $0.405^{* *}$ & $0.477 * *$ & 0.108 \\
\hline & \multicolumn{4}{|c|}{2002} \\
\hline Density & $0.381 * *$ & $0.387 * *$ & $0.324 *$ & $0.369 * *$ \\
\hline \multirow[t]{2}{*}{ Biomass } & $0.256^{*}$ & $0.341 * *$ & 0.209 & $0.358^{* *}$ \\
\hline & \multicolumn{4}{|c|}{2003} \\
\hline Density & $0.420 * *$ & $0.488^{* *}$ & $0.392 * *$ & $0.413 * *$ \\
\hline Biomass & $0.399 * *$ & $0.381 * *$ & $0.340 * *$ & $0.377 * *$ \\
\hline
\end{tabular}

$*$ and $* *$ significant at 5 an $1 \%$ of probability, respectively. 
non-arable habitats than in ploughed ones (Ivask et al., 2007; Smith et al., 2008). This may be the reason for their absence in the field centre. Similarly, the deepburrowing earthworm L. terrestris, which collects food from the soil surface, is adversely affected by heavy soil cultivation that destroys its burrow system and reduces food sources. The preference of $A$. rosea and $O$. lacteum, which can withstand ploughing rather well (Whalen, 2004), for the forest edge and periphery of the field could be explained by better moisture conditions, as reflected by the presence of the amphibious E. tetraedra in the same transect rows.

The forest edge had a positive effect on the density and biomass of earthworms. In general, both parameters were higher in the ecotone zone than in the forest or in adjacent parts of the field. These findings contradict what was found in Sweden by Lagerlöf et al. (2002), who reported lower earthworm density and biomass in the boundary and periphery than in more distant parts of an arable field. Similar to our study, however, they found the highest earthworm density in the field centre. Correspondingly, A. caliginosa was identified as the dominant species in both studies. This endogeic earthworm lives in horizontally oriented semi-permanent burrows in the mineral layers of the soil. It occurs commonly in agro-ecosystems and is known to be resistant to cultivation (Smith et al., 2008). Even after shifting tillage practice from ploughing to reduced-tillage stubble cultivation or direct drilling, followed by the rapid increase of $L$. terrestris and D. rubidus populations, the populations of A. caliginosa often remained unchanged (Nuutinen, 1992). Studies on earthworm succession in abandoned fields showed that $A$. caliginosa seems to be a species of the open landscape, which declines as soon as afforestation occurs (Scheu, 1992; Pižl, 1999). Slávecz \& Csuzdi (2007) reported from Maryland, USA, that the introduced $A$. caliginosa dominated even in successional forests, whereas another introduced species, L. rubellus, dominated in the mature forests. The highest density of $A$. caliginosa in the lines most distant from the field boundary found in our study may probably result from lower level of competition, higher soil $\mathrm{pH}$ and redistribution of organic food sources through the profile of the loosened soil.

Makulec (2004) found no significant difference between the midfield shelterbelt and the ecotone in either composition (three species: A. caliginosa,
D. octaedra and L. terrestris) or mean density of lumbricids (58 and 73 individuals $\mathrm{m}^{-2}$, respectively). Again, A. caliginosa was the dominant earthworm. However, he found a single species, A. caliginosa, at an extremely low density ( 0.9 individuals $\left.\mathrm{m}^{-2}\right)$ in an adjacent maize field. Nowak (2004), who carried out her study in the same area, concluded that the assemblages of enchytraeids in the ecotones were similar to those in the fields with respect to species composition, and to those in shelterbelts with respect to the density and body size.

\section{Conclusion}

Forest edges may play a positive role in the maintenance of earthworm species richness in agroecosystems.

\section{Acknowledgements}

Our research was supported by the Ministry of Education, Youth and Sports of the Czech Republic and by the Academy of Sciences of the Czech Republic.

\section{References}

ARUJO, Y.; LOPEZ-FERNANDEZ, D. Earthworm populations in a savanna-agroforestry system of Venezuelan Amazonia. Biology and Fertility of Soils, v.29, p.413-418, 1999.

HÁNĚL, L. Microgradient changes of soil nematodes (Nematoda) in litter and moss-lichen transects in spruce and beech forests. Acta Societatis Zoologicae Bohemicae, v.64, p.27-36, 2000.

IMAZ, A.; HERNÁNDEZ, M.A.; ARIÑO, A.H.; ARMENDÁRIZ, I.; JORDANA, R. Diversity of soil nematodes across a Mediterranean ecotone. Applied Soil Ecology, v.20, p.191-198, 2002.

IVASK, M.; KUU, A.; SIZOV, E. Abundance of earthworm species in Estonian arable soils. European Journal of Soil Biology, v.43, p.39-42, 2007.

LAGERLÖF, J.; GOFFRE, B.; VINCENT, C. The importance of field boundaries for earthworms (Lumbricidae) in the Swedish agricultural landscape. Agriculture, Ecosystems \& Environment, v.89, p.91-103, 2002.

LEOPOLD, A. Game Management. Madison: University of Wisconsin Press, 1933. 481p.

MAKULEC, G. Lumbricidae communities in several years old midfield shelterbelt (Turew region, western Poland). Polish Journal of Ecology, v.52, p.173-179, 2004.

MATHER, J.G.; CHRISTENSEN, O. Surface movements of earthworms in agricultural land. Pedobiologia, v.32, p.399-405, 1995.

NOWAK, E. Enchytraeids (Oligochaeta) in the agricultural landscape. Polish Journal of Ecology, v.52, p.115-122, 2004. 
NUUTINEN, V. Earthworm community response to tillage and residue management on different soil types in southern Finland. Soil and Tillage Research, v.23, p.221-239, 1992.

PIŽL, V. Earthworm succession in abandoned fields - a comparison of deductive and sequential approaches to study. Pedobiologia, v.43, p.705-712, 1999.

SCHEU, S. Changes in the lumbricid coenosis during secondary succession from a wheat field to a beechwood on limestone. Soil Biology and Biochemistry, v.24, p.1641-1646, 1992.

SKLENIČKA, P.; LHOTA, T.; ČEČETKA, J. Soil porosity along a gradient from forest edge to field. Bodenkultur, v.53, p.191-197, 2002.

SLÁVECZ, K.; CSUZDI, C. Land use change affects earthworm communities in Eastern Maryland, USA. European Journal of Soil Biology, v.43, p.79-85, 2007.
SLAWSKI, M.; SLAWSKA, M. The forest edge as a border between forest and meadow. Vegetation and Collembola communities. Pedobiologia, v.44, p.442-450, 2000.

SMITH, R.G.; MCSWINEY, C.P.; GRANDY, A.S.; SUWANWAREE, P.; SNIDER, R.M.; ROBERTSON, G.P. Diversity and abundance of earthworms across an agricultural land-use intensity gradient. Soil and Tillage Research, v.100, 83-88, 2008.

WHALEN, J.K. Spatial and temporal distribution of earthworm patches in corn field, hayfield and forest systems of southwestern Quebec, Canada. Applied Soil Ecology, v.27, p.143-151, 2004.

ZBÍRAL, J.; HONSA, I.; MALÝ, S. Soil Analyses, part III. Brno: Czech Central Institute for Supervising and Testing in Agriculture, 1997. 150p.

$\overline{\text { Received on September 27, } 2008 \text { and accepted on July 2, } 2009}$ 